\title{
SENTRA KULAKAN SOLUSI PERMASALAHAN UMKM DAN MASYARAKAT MISKIN
}

\author{
Wahyu Wiyani ${ }^{1}$, Boge Triatmanto ${ }^{2)}$ \\ Fakultas Ilmu Sosial dan Ilmu Politik, Universitas Merdeka Malang ${ }^{1)}$ \\ Fakultas Ekonomi, Universitas Merdeka Malang ${ }^{2}$
}

\begin{abstract}
Abstrak
Kebijakan kemudahan pemberian fasilitas mendirikan gerai retail (Alfamart, Indomaret, dll) mengakibatkan banyaknya toko/pracangan yang gulung tikar, hal ini dikarenakan toko/pracangan belum bisa memenuhi kebutuhan masyarakat yang semakin beragam, selain itu persaingan harga yang terjadi antara toko/pracangan dengan retail menyebabkan orang beralih membeli ketoko retail yang harga produk persatuannya relatif lebih murah, sehingga barang yang dijual oleh toko/pracangan tidak laku akhirnya harus ditutup. Hal demikian juga dialami oleh UMKM yang membeli barang di toko/pracangan, dengan ditutupnya pracangan mereka kesulitan mendapatkan pasokan bahan, karena jika membeli ditoko atau pasar mereka harus mengeluarkan biaya transport yang relatif besar, sehingga keuntungan mereka menjadi berkurang.Untuk mengatasi hal tersebut maka perlu dibuat wadah/toko tempat kulakan bagi toko/pracangan dan UMKM dengan harga yang murah dan jenis barang yang beragam. Pendirian sentra kulakan ini diharapkan bisa meningkatkan atau menghidupkan kembali toko pracangan dan UMKM yang telah mati, dengan memberikan kepastian pasokan barang dengan harga murah dan dapat diangsur pembayarannya.
\end{abstract}

Kata Kunci : Toko pracangan, UMKM, Sentra Kulakan

\section{PENDAHULUAN}

Banyaknya gerai retail modern yang didirikan diwilayah pedesaan menyebabkan toko-toko pracangan harus menutup usahanya karena kalah bersaing, merupakan keprihatinan kita bersama untuk mencari solusi apa yang bisa dilakukan agar toko pracangan ini bisa eksis kembali, toko pracangan yang memasok bahan baku bagi UMKM ini harus terus didorong untuk terus bertahan dan berkembang, sehingga tingkat kemiskinan bisa ditekan terutama dengan memberdayakan ekonomi masyarakat kecil melalui pembukaan warungwarung dalam jaringan sentra kulakan, upaya pemberdayaan masyarakat melalui kegiatan ekonomi itu dilakukan dengan cara memberikan kredit atas barang-barang dagangan dari sentra kulakan

Indonesia merupakan pasar potensial bagi bisnis retail modern yang dibuktikan dengan pertumbuhan jumlah gerai rata-rata sebesar $17,5 \%$ pertahun selama tahun 2007 sampai 2012 (Apipudin, 2013). Hingga tahun 2015 ini telah berdiri kurang lebih 150 gerai retail modern di wilayah Malang Raya. Menjamurnya toko modern yang ada menyebabkan pelaku usaha kecil terutama toko tradisional yang berada disekitar mengalami penurunan omzet penjualan yang cukup drastis, bahkan harus ditutup. Hal ini juga terjadi diwilayah Ngijo Kec
Karangploso, dan desa Kalirejo serta desa Ketindan Kec Lawang. Ditiga desa tersebut banyak toko kelontong yang harus tutup karena kalah bersaing dengan usaha retail, sementara UMKM banyak yang menghentikan usaha karena meningkatnya harga bahan. Adanya sentra kulakan ini diharapkan akan dapat menggairahkan kegiatan usaha mereka kembali dan menaikkan ekonomi pelaku UMKM maupun keluarga, terutama keluarga miskin.

\section{METODE KEGIATAN}

Pembentukan Sentra Kulakan dimulai dari kegiatan identifikasi kondisi diketiga wilayah kerja, kemudian dilanjutkan dengan penentuan sentra kulakan induk baik pengelola maupun lokasi , pelatihan penguatan manajemen, persiapan sarana prasarana, kegiatan operasional, pemantauan. 7 Maret 2015 telah disepakati dibentuk sentra kulakan Lumbung Artha Jaya di desa Ngijo Karangploso, dengan diketuai oleh Ibu Erlin (ketua Kopwan Pundi Artha Jaya). Pada bulan April 2015 persiapan operasional sentra kulakan dengan menyediakan barang dan infrastruktur pendukung. Awal Mei 2015 kegiatan sentra kulakan sudah berjalan. 


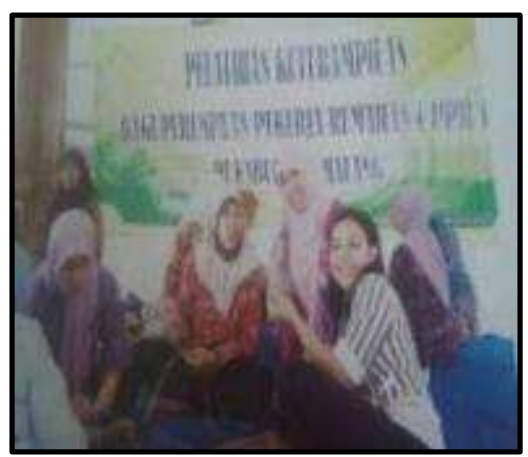

Gbr. 1. Pelatihan Pembukuan Sederhana

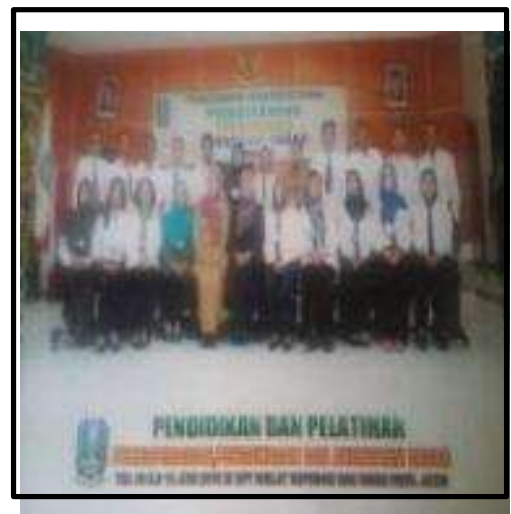

Gb 2. Pelatihan Perkoperasian, Pengawasan dan Akuntansi Dasar

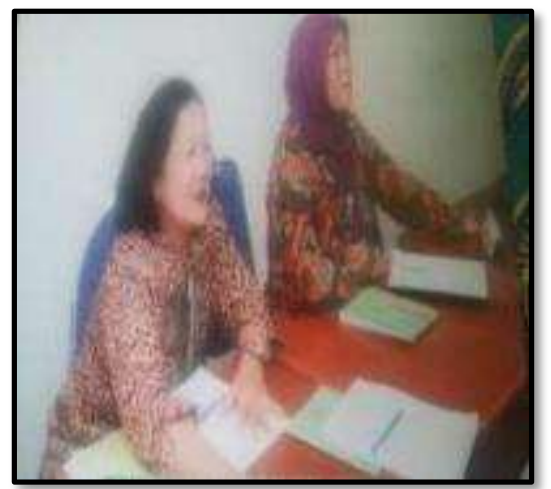

Gb 3.Pelatihan Perpajakan

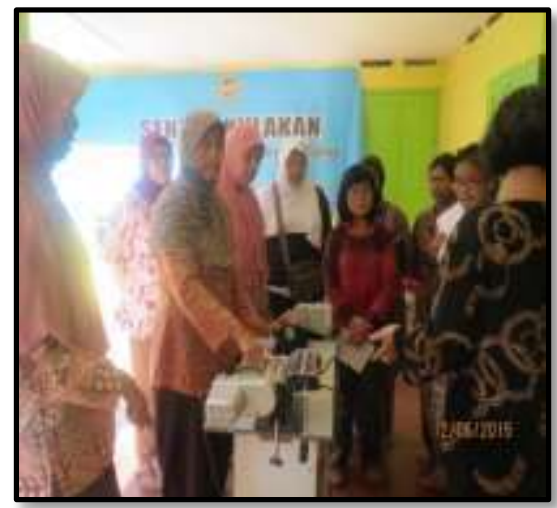

Gb 4. Pelatihan Pembuatan Kue Kering

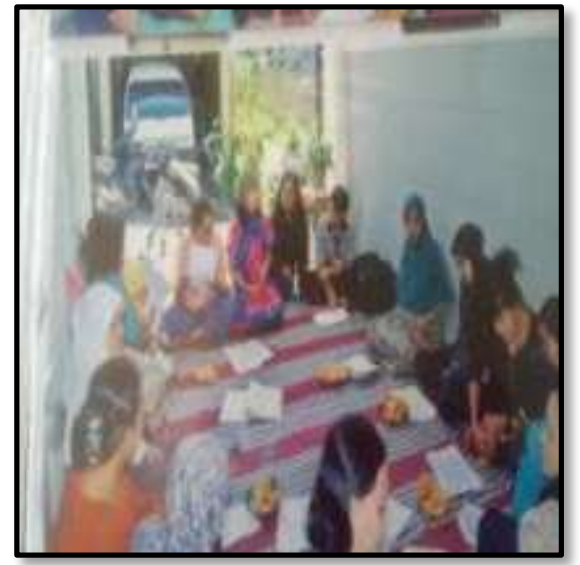

Gbr. 5 Pelatihan Pembuatan Kue kering dan Kue Basah

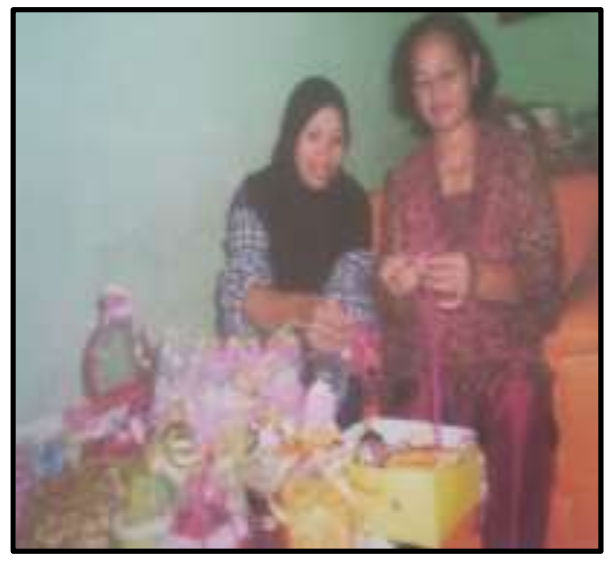

Gb 6. Pelatihan Pembuatan Handycraft

Selain pelatihan, tim juga memberikan stimulan berupa barang dagangan, software komputer akuntansi serta, kendaraan niaga berupa sepeda TOSA

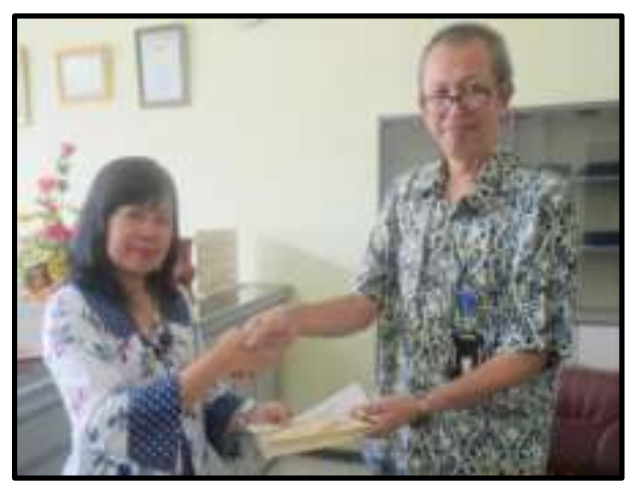

Gb 7. Penyerahan Nota Belanja dan Software Program Akuntansi 


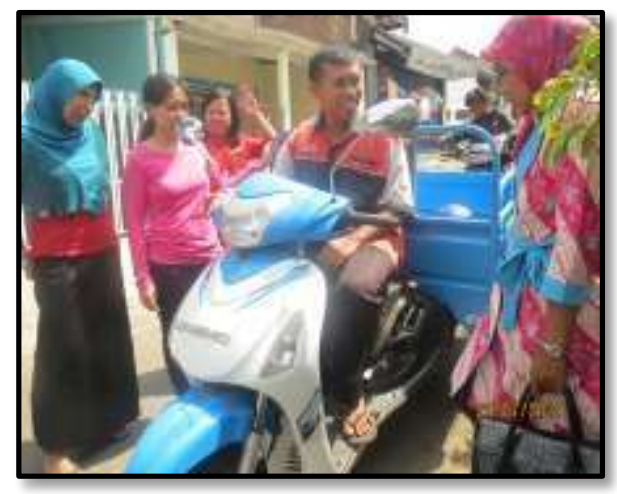

Gb 8 Penyerahan Kendaraan Niaga TOSA

\section{HASIL DAN KEGIATAN}

Karya Utama dari kegiatan pengabdian kepada masyarakat ini adalah terbentuknya sentra kulakan yang bisa meningkatkan kegiatan ekonomi masyarakat terutama UMKM dan mayarakat miskin. Pemberdayaan ekonomi kerakyatan, seperti koperasi usaha mikro, kecil, dan menengah merupakan upaya strategis dalam rangka mewujudkan kesejahteraan masyarakat, karena KUMKM merupakan bagian terbesar dari aktivitas masyarakat Indonesia. Sentra Kulakan menjadi salah satu pendukung penting kegiatan ekonomi kerakyatan. "Pendirian sentra kulakan bertujuan untuk menumbuhkan peluang serta kesempatan ekonomi di sektor perdagangan untuk Kelompok Usaha Mikro, Kecil dan Menengah (KUMKM, red sentra kulakan, lebih diorientasikan untuk memasok barang dagangan ke para pedagang atau pun kelompok UKM dengan modal pas-pasan)," kata Menteri Negara Koperasi dan UKM Dr Syarifuddin Hasan, MM, MBA.. sentra kulakan jangan sampai mematikan warung-warung kecil. Sentra kulakan harus bisa memperkuat warung kecil yang omzet sebelumnya sedikit menjadi meningkat. Adanya sentra kulakan yang jaraknya tidak jauh dari lokasi tempat usaha mereka, harapannya bisa menekan/meniadakan ongkos transport, harga barang yang lebih murah serta pembayaran yang bisa ditunda..

Sentra kulakan yang dibentuk tim pada awalnya hanya 3 yakni Lumbung Artha Jaya di desa Ngijo Kecamatan Karangploso (sebagai induk), Ketindan Sari di desa Ketindan Kecamatan Lawang dan Kaliartho didesa Kalirejo Kecamatan Lawang (sebagai binaan). Namun dalam perkembangannya ada beberapa sentra binaan lain yang dibentuk dan sampai dengan bulan September 2015 telah terbentuk 12 ( 1 induk dan 11 binaan)
Selain terbentuk beberapa sentra kulakan baru, kegiatan yang lain adalah membina UMKM baik yang baru maupun yang sudah lama namun tidak berkembang. Adanya sentra kulakan ini mendapat respon dari pelaku UMKM untuk membuka kembali usahanya dan ada pula yang membuka usaha baru dengan menggunakan fasilitas pembelian bahan dari sentra dengan cara pembayaran mengangsur.
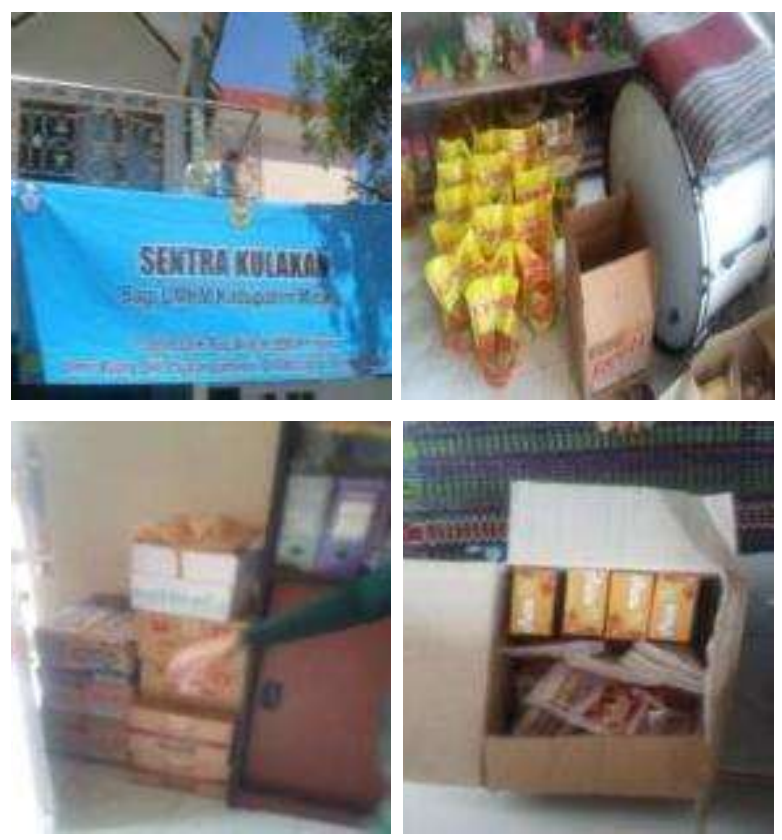

Gb. 9. Sentra Kulakan Lumbung Artha Jaya Ngijo Karangploso
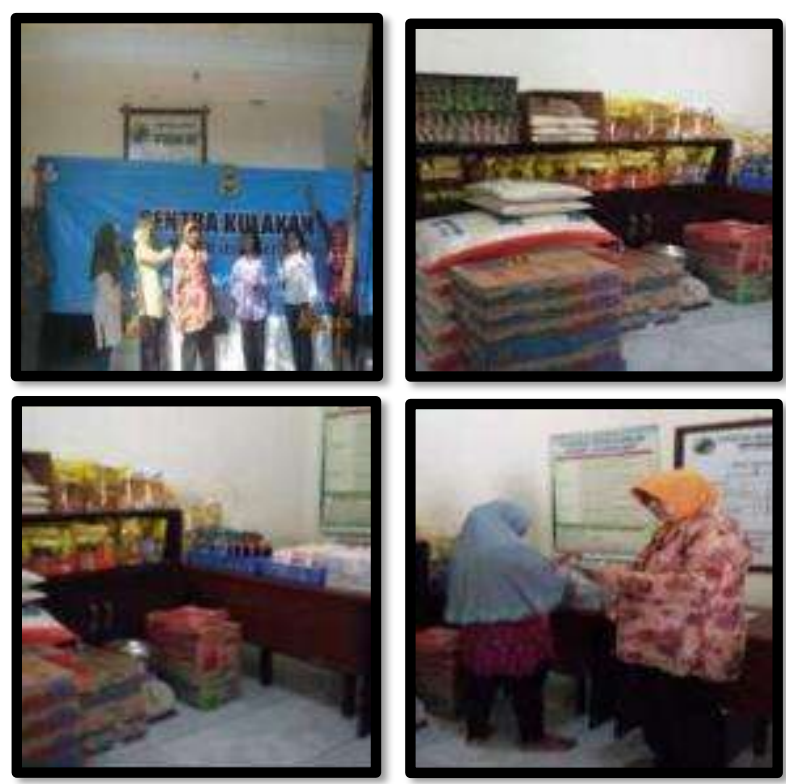

Gb 10. Sentra Kulakan Ketindan Sari Lawang 

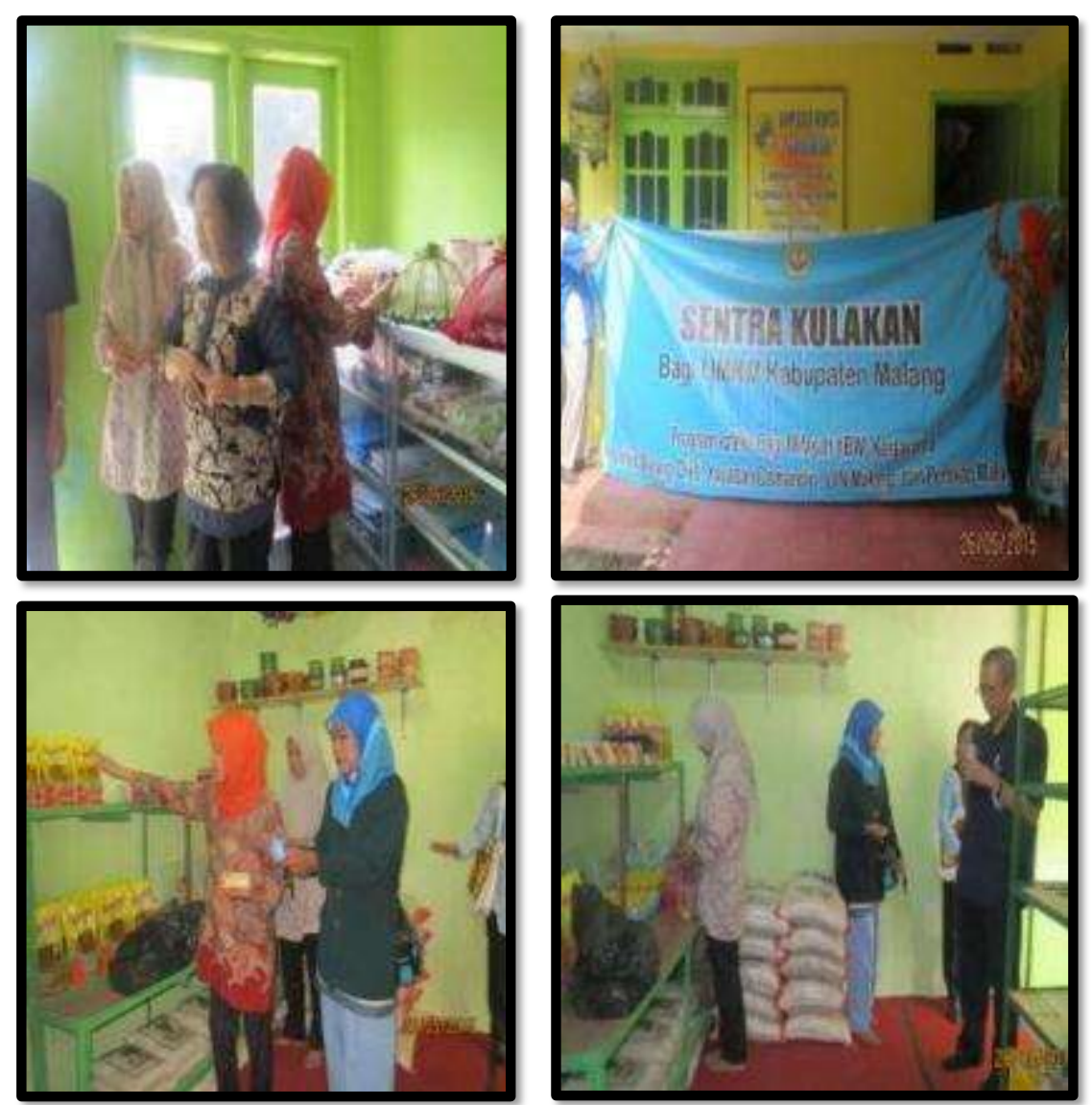

Gb 11. Sentra Kulakan Kaliartho Lawang

Perkembangan usaha selama 5 bulan mulai Mei s/d September 2015 sangat bagus, hal ini bisa dilihat dari kondisi keuangan dengan stimulan barang dagangan awal sebesar Rp 23.838.370,berjalan 5 bulan total belanja telah mencapai $\mathrm{Rp}$ 64.60.570,- , penjualan bulan pertama operasional sebesar Rp 15.194.290,- setelah 5 bulan mencapai Rp 43.719.017,-- sedangkan laba operasi bulan pertama Rp 903.720,- selama 5 bulan telah mencapai Rp. 3.590.458,-, hal ini bisa dilihat pada tabel berikut:

Tabel 1. Perkembangan usaha sentra kulakan

\begin{tabular}{cllll} 
Bulan & Belanja & Penjualan & & Laba \\
\hline Mei & Rp 23.838.370,- & Rp 15.194.290,- & Rp 903.720,- \\
\hline Juni & Rp 16.252.600,- & Rp 14.323.277,- & Rp 583.278,- \\
\hline Juli & Rp 10.056.400,- & Rp 7.627.900,- & Rp 758.710,- \\
\hline Agustus & Rp 4.927.000,- & Rp 3.038.000,- & Rp 645.400,- \\
September & Rp 9.532.200.- & Rp 3.535.550,- & Rp 699.350,- \\
\hline TOTAL & $R p 64.606 .570,-$ & $R p 43.719 .017,-$ & $R p ~ 3.590 .458,-$ \\
\hline
\end{tabular}


Sebagaimana harapan kita bersama adanya sentra kulakan (SK) ini, walaupun kecil mampu menghidupkan kembali UMKM yang ada disekitar sentra kulakan. Jika dilihat dari perkembangan sentra kulakan dan UMKM yang bisa hidup kembali upaya pembentukan sentra kulakan ini telah membuahkan hasil.
Perkembangan sentra kulakan April 2015 hanya 1, Bulan Mei 2015 berkembang menjadi 3 dan sampai September 2015 telah terbentuk 12 sentra kulakan, sementara UMKM yang bisa dikembangkan oleh sentra kulakan yang telah ada berjumlah 14 usaha rumahan

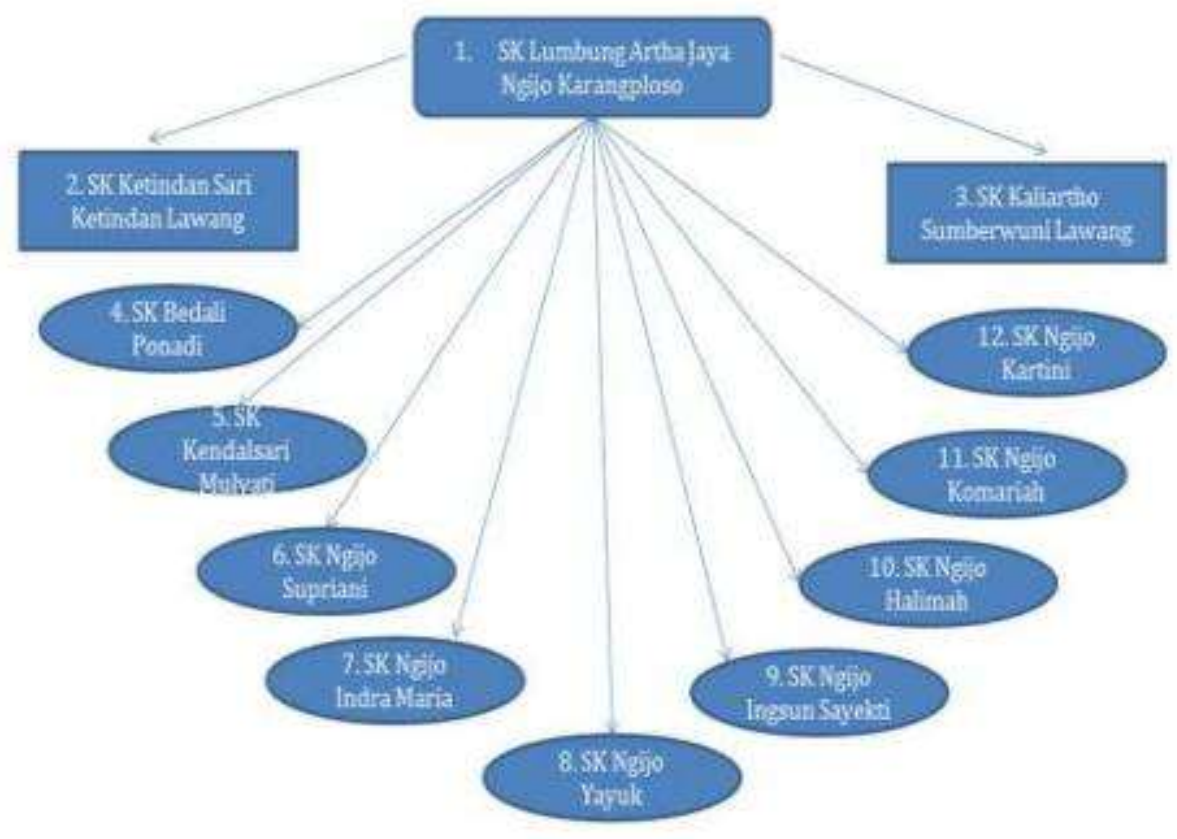

Gb. 12 Sentra Kulakan (SK) yang terbentuk
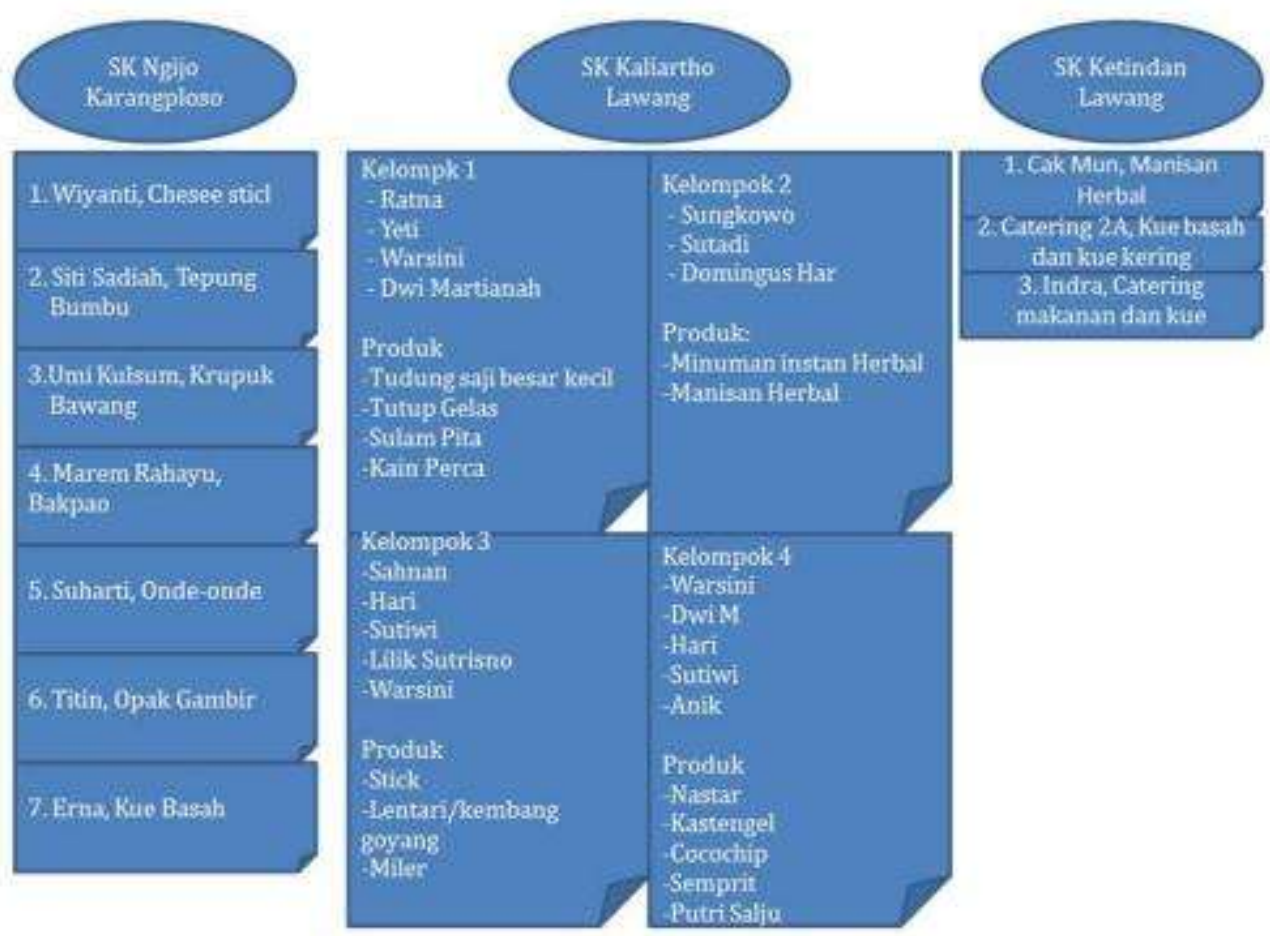

Gb 13. UMKM Binaan Sentra Kulakan 


\section{KESIMPULAN}

\subsection{Kesimpulan}

a. Kemiskinan merupakan masalah kita bersama, dengan memberikan sedikit sentuhan kepada masyarakat peduli wong cilik, kemiskinan bisa kita tekan.

b. Salah satu media efektif untukmengurangi angka kemiskinan adalah sentra kulakan, karena adanya sentra kulakan dilingkungan masyarakat akan membantu keluarga miskin dan usaha mikro untuk mendapatkan pasokan barang dengan harga relatif lebih murah, tanpa biaya transportasi yang semakin meningkatkan harga perolehan barang

\subsection{Saran}

a. Pemerintah Daerah didalam membuat regulasi hendaknya lebih berpihak kepada golongan bawah, jangan hanya memihak pada pemodal b. Tegakkan aturan dalam pemberian ijin usaha retail yang selama ini telah dilanggar, salah satunya adalah aturan jarak, dalam aturan jarak antara satu retail dengan retail lainnya minimal $500 \mathrm{~m}$, namun saat ini banyak retail yang berjarak kurang dari $500 \mathrm{~m}$ dan bahkan berdampingan/berhadapan, sehingga mematikan usaha warung, toko dan pracangan yang ada disekitarnya.

\section{DAFTAR PUSTAKA}

http://www.lensaindonesia.com/2012/10/12/men kop-ukm-resmikan-sentra-kulakan-posdayadi- pacitan.html

http://www.gemari.or.id/cetakartikel.php?id=6051 Sentra Kulakan Posdaya Pacitan Wujud Pro Ekonomi Kerakyatan 